\title{
Analisis Implementasi Akuntansi Berbasis Akrual pada Inspektorat Jenderal Kementerian Keuangan
}

\author{
Eliada Herwiyanti ${ }^{*}$, Sukirman ${ }^{1}$, Fairuz Sufi Aziz ${ }^{1}$ \\ ${ }^{1}$ Fakultas Ekonomi dan Bisnis, Universitas Jenderal Soedirman, Purwokerto, Indonesia \\ * Penulis korespondensi; E-mail: elly_idc@yahoo.com
}

\begin{abstract}
ABSTRAK
Penelitian ini merupakan penelitian kualitatif terhadap penerapan Sistem Akuntansi Pemerintahan berbasis akrual di lingkungan Inspektorat Jenderal Kementerian Keuangan. Tujuan dari penelitian ini adalah untuk mengetahui bagaimana kesiapan dan penerapan SAP Berbasis Akrual di instansi tersebut. Data dalam penelitian ini dikumpulkan melalui observasi, studi kepustakaan, serta wawancara terhadap sepuluh orang informan yang terkait langsung dengan penerapan SAP berbasis akrual. Data yang telah dikumpulkan kemudian dianalisis dan diinterpretasikan secara naratif dengan menggunakan metode analisis data kualitatif yang direkomendasikan oleh Creswell (2012). Hasil penelitian ini menunjukkan bahwa secara umum, kesiapan Itjen Kemenkeu dalam menerapkan sistem akuntansi akrual sudah baik, mulai dari aspek komunikasi, sumber daya, komitmen organisasi, dan struktur birokrasi. Dengan kesiapan yang baik, penelitian ini juga menunjukkan bahwa penerapan sistem akuntansi akrual di Itjen Kemenkeu sudah dilakukan dengan sangat memuaskan, yang ditunjukkan dengan nilai sebesar $93,40 \%$.
\end{abstract}

Kata kunci: SAP berbasis akrual; implementasi; kebijakan akuntansi pemerintah pusat.

\begin{abstract}
This study is a qualitative research on the implementation of the Accrual Based Government Accounting System in the Inspectorate General of Ministry of Finance. This study aims to find how the Accrual Based Government Accounting System was prepared and implemented in the institution. Data were collected through observation, study of literature, and interviews with ten participants who have been involved in the implementation of the system. The data were analyzed and interpreted narratively that are recommended by Creswell (2012). This study found that the readiness of Inspectorate General of the Ministry of Finance in implementing accrual accounting system was good, either from the communication aspect, resource aspect, organizational commitment aspect, and bureaucratic structure aspect. Moreover, this study concluded that the implementation of accrual accounting system in the institution is well performed, that has scored $93.40 \%$.
\end{abstract}

Keywords: accrual basis of GAS; implementation; accounting policy of central government.

\section{PENDAHULUAN}

Reformasi Keuangan Negara ditandai dengan lahirnya paket Undang-Undang (UU) di bidang Keuangan Negara yang terdiri dari UU 17 Tahun 2003, UU 1 Tahun 2004, dan UU 15 Tahun 2004. Ketiga UU ini mengamanatkan pentingnya tata kelola keuangan yang baik (Good Governance) berdasarkan prinsip-prinsip transparansi dan akuntabilitas, serta mengikuti praktik terbaik taraf internasional (international best practices) yang disesuaikan dengan kondisi di Indonesia. Reformasi keuangan negara sebagaimana yang diamanatkan UU 17 Tahun 2003 mencakup reformasi di bidang akuntansi dan pelaporan keuangan pemerintah (Harun, 2012).

Pasal 36 ayat 1 UU 17 Tahun 2003 tentang Keuangan Negara mengamanatkan bahwa ketentuan mengenai pengakuan dan pengukuran pendapatan dan belanja berbasis akrual sebagaimana dimaksud dalam Pasal 1 angka 13, 14, 15, dan 16 undang-undang ini dilaksanakan selambat-lambatnya dalam 5 (lima) tahun. Jika pengakuan dan pengukuran pendapatan dan belanja berbasis akrual belum dilaksanakan, maka digunakan pengakuan dan pengukuran berbasis kas. 
Dua tahun setelah UU 17 Tahun 2003 diundangkan, pemerintah mengeluarkan PP 24 Tahun 2005 tentang Standar Akuntansi Pemerintahan (SAP). SAP tersebut merupakan standar akuntansi pemerintahan pada masa transisi dari basis kas menuju basis akrual yang dinamakan Cash toward Accrual. Namun hingga akhir tahun 2008, lima tahun setelah amanat UU 17 Tahun 2003, pemerintah masih belum dapat menerapkan akuntansi berbasis akrual secara penuh (Kusmanadji, 2014). Baru pada tahun 2010 pemerintah mengeluarkan PP 71 Tahun 2010 tentang Standar Akuntansi Pemerintahan, yang meliputi SAP berbasis akrual dan SAP berbasis kas menuju akrual.

SAP berbasis akrual diatur dan dijelaskan dalam Lampiran I PP 71 Tahun 2010 tentang Standar Akuntansi Pemerintahan. Aturan tersebut berlaku sejak tanggal 22 Oktober 2010 dan dapat segera diterapkan oleh setiap entitas. Sementara itu, SAP berbasis kas menuju akrual yang diatur dan dijelaskan pada Lampiran II peraturan tersebut dapat diterapkan oleh entitas yang belum siap menerapkan SAP berbasis akrual sampai dengan jangka waktu paling lama 4 (empat) tahun setelah tahun anggaran 2010, yaitu tahun 2014. Artinya, pada tahun 2015 ini seluruh entitas pelaporan dan akuntansi sudah harus menerapkan akuntansi berbasis akrual.

Oleh karena itu, pada tanggal 4 Maret 2015 Kementerian Keuangan menyelenggarakan permulaan (Kick Off) Implementasi Akuntansi Pemerintahan Berbasis Akrual, bertempat di Aula Mezzanine Gedung Djuanda I Kementerian Keuangan. Penyelenggaraan acara Kick Off Implementasi Akuntansi Pemerintahan Berbasis Akrual ditujukan untuk menciptakan momentum awal penerapan implementasi akuntansi pemerintahan berbasis akrual serta guna menciptakan semangat dan komitmen kuat pada pimpinan Kementerian Negara/Lembaga terhadap implementasi akuntansi pemerintahan berbasis akrual dengan tetap mempertahankan peningkatan kualitas pelaporan keuangan (Kementerian Keuangan, 2015).

Namun pada tanggal 30 Oktober 2015, Direktur Jenderal Perbendaharaan Kementerian Keuangan menerbitkan surat nomor S-9180/PB/ 2015 tentang Penyusunan Pseudo Laporan Keuangan Tahun 2015 yang menyatakan bahwa masih terdapat berbagai permasalahan dalam penyusunan Laporan Keuangan Kementerian Lembaga (LKKL) Semester I Tahun 2015 berkenaan dengan implementasi akuntansi berbasis akrual. Oleh karena itu perlu dilakukan evaluasi dan penelitian mendalam atas penerapan akuntansi berbasis akrual. Secara ringkas, Tabel 1 mengilustrasikan kronologi reformasi akuntansi di Indonesia.
Tabel 1. Kronologi Reformasi Akuntansi

\begin{tabular}{|c|c|}
\hline Tahun & Kejadian Penting \\
\hline 2003 & $\begin{array}{l}\text { Penerbitan UU No. } 17 \text { Tahun } 2003 \text { yang meng- } \\
\text { amanatkan penggunaan basis akrual dalam } \\
\text { pengakuan dan pengukuran pendapatan dan } \\
\text { belanja negara. }\end{array}$ \\
\hline 2005 & $\begin{array}{l}\text { Penerbitan PP } 24 \text { Tahun } 2005 \text { tentang Standar } \\
\text { Akuntansi Pemerintahan berbasis Kas Menuju } \\
\text { Akrual. }\end{array}$ \\
\hline 2010 & $\begin{array}{l}\text { Penerbitan PP } 71 \text { Tahun } 2010 \text { tentang Standar } \\
\text { Akuntansi Pemerintahan berbasis Akrual } \\
\text { dengan masa transisi } 4 \text { tahun. }\end{array}$ \\
\hline 2015 & $\begin{array}{l}\text { Kick Off Implementasi Akuntansi Pemerin- } \\
\text { tahan Berbasis Akrual. }\end{array}$ \\
\hline 2015 & $\begin{array}{l}\text { Penerbitan Surat Direktur Jenderal Perben- } \\
\text { daharaan Kementerian Keuangan nomor S- } \\
\text { 9180/PB/2015 hal Penyusunan Pseudo Laporan } \\
\text { Keuangan Tahun } 2015 \text {. }\end{array}$ \\
\hline
\end{tabular}

Di negara maju seperti Australia, Selandia Baru, dan Inggris, sistem akuntansi akrual telah diadopsi ke dalam sektor publik sejak tahun 1970an sebagai hasil perkembangan praktik New Public Management (NPM) (Ryan, 1998, Lye et al., 2005). Sejak pengadopsian akuntansi akrual oleh organisasi sektor publik di banyak negara maju, banyak peneliti yang berusaha memahami latar belakang pengadopsian dan melakukan penilaian tingkat keberhasilannya. Ryan (1998) melakukan pengujian mengenai proses pengadopsian sistem akuntansi akrual pada organisasi sektor publik di Australia. Ryan (1998) menyatakan bahwa kebijakan pengadopsian sistem akuntansi akrual di Australia bertujuan untuk meningkatkan pencatatan dan pengukuran terkait pengeluaran pemerintah. Hal itu menunjukkan bahwa praktik NPM yang didasarkan pada teori ekonomi merupakan alasan dilakukannya adopsi sistem akuntansi akrual pada organisasi sektor publik.

Sebagaimana penelitian Ryan (1998), penelitian yang dilakukan oleh Lye et al. (2005) di Selandia Baru juga menemukan hal yang sama bahwa motif ekonomi merupakan alasan di balik pengadopsian sistem akuntansi akrual pada organisasi sektor publik. Hal tersebut disimpulkan berdasarkan temuan mereka bahwa kebutuhan untuk mengadopsi sistem akuntansi sektor publik yang komprehensif bertujuan untuk memulihkan kondisi ekonomi negara yang saat itu sedang menghadapi kenaikan utang pemerintah di tahun 1970-an dan 1980-an.

Tidak seperti di Australia dan Selandia Baru sebagaimana dijelaskan di atas, pengenalan dan pengadopsian sistem akuntansi akrual di negaranegara berkembang didorong oleh persyaratan yang diberikan oleh otoritas pendanaan internasional seperti Bank Dunia atau IMF. Hasil penelitian El-Batononi dan Jones (1996) menunjukkan 
bahwa pemerintah Sudan yang berusaha untuk mengadopsi akuntansi akrual pada sektor publik dilatarbelakangi oleh agen pembiayaan internasional. Senada dengan penelitian tersebut, penelitian yang dilakukan di Fiji (Sharma dan Lawrence, 2008) dan Ghana (Rahaman, 2009) juga memperlihatkan bahwa pengadopsian akuntansi dan audit keuangan bergaya swasta dalam organisasi sektor publik pada negara-negara tersebut didorong oleh lembaga donor internasional.

Hasil penelitian-penelitian di atas telah memberikan pemahaman bahwa terdapat dua jenis motivasi yang mendasari pengadopsian sistem akuntansi akrual yaitu motif ekonomi yang didorong oleh aktor di dalam organisasi, dan motif kekuasaan yang didorong oleh aktor di luar organisasi. Perbedaan motif tersebut akan memberikan hasil yang berbeda dalam penerapan sistem akuntansi akrual. Tidak seperti Selandia Baru yang mempunyai motif ekonomi dan mengadopsi sistem secara komprehensif, pengadopsian sistem yang dilakukan secara minimal akan menimbulkan fenomena decoupling yang membuat sistem tersebut diterapkan secara seremonial (Dambrin et al., 2007). Tekanan dari aktor di luar organisasi dan kegagalan proses internalisasi pada negara yang "dipaksa" mengadopsi sistem akuntansi akrual dikhawatirkan akan mendorong terjadinya fenomena decoupling.

Harun dan Eggleton (2012) melakukan penelitian mengenai proses institusionalisasi sistem akuntansi akrual di salah satu pemerintah kota di Indonesia. Hasil penelitian tersebut menunjukkan bahwa awal mula pengadopsian sistem akuntansi akrual di Indonesia didorong oleh beberapa peristiwa seperti krisis minyak pada tahun 1983 dan juga krisis moneter pada tahun 1998. Krisis minyak pada tahun 1983 memberikan dampak yang signifikan terhadap perekonomian negara waktu itu termasuk tingginya tingkat inflasi, dan krisis moneter pada tahun 1998 memperparah kejadian tersebut sehingga timbul tekanan sosial dari masyarakat pada akhir 1990-an. Kejadiankejadian tersebut telah menginspirasi teknokratteknokrat di Kementerian Keuangan untuk mendorong dilakukannya reformasi akuntansi sektor publik yang menurut mereka akan dapat memberikan pengendalian pada pengeluaran pemerintah dan menggambarkan kinerja pemerintah.

Hasil penelitian Harun dan Eggleton (2012) seolah-olah menggambarkan bahwa pengadopsian sistem akuntansi yang dilakukan oleh pemerintah Indonesia didasarkan pada motif ekonomi sebagaimana yang dilakukan oleh pemerintah Australia dan Selandia Baru. Namun, Harun dan Eggleton (2012) menemukan fenomena pemisahan aktivitas (decoupling) di salah satu pemerintah kota yang menjadi lokasi penelitiannya.
SAP berbasis akrual yang seharusnya meningkatkan efisiensi malah menambah biaya pada pemerintah kota tersebut. Selain itu juga tidak terlihat adanya peningkatan akuntabilitas.

\section{RUMUSAN MASALAH}

Berdasarkan latar belakang masalah yang telah dikemukakan, maka rumusan permasalahan yang hendak diselesaikan dalam penelitian ini adalah (1) Bagaimana kesiapan Inspektorat Jenderal Kemenkeu (Itjen) dalam menerapkan sistem akuntansi akrual? dan (2) Bagaimana penerapan sistem akuntansi akrual di Itjen Kemenkeu?

\section{LANDASAN TEORI}

\section{Teori Ekonomi}

Praktik NPM yang mendasari pada teori ekonomi merupakan alasan dilakukannya adopsi sistem akuntansi akrual pada organisasi sektor publik. Dari perspektif teori ekonomi, dikatakan bahwa akuntabilitas dan kinerja organisasi sektor publik dapat ditingkatkan dengan mentransformasikan proses manajemen, evaluasi, dan pendanaan organisasi sektor publik ke dalam praktik manajemen sektor swasta (Harun dan Kamase, 2012). Di bawah prinsip-prinsip NPM, sejak tahun 1980-an praktik business-style dalam organisasi sektor publik di seluruh dunia telah dikembangkan (Broadbent dan Guthrie, 2008).

Lapsley dan Pallot (2000) menyatakan bahwa filosofi NPM berasal dari tiga paradigma yaitu teori pilihan publik (public choice theory), teori keagenan (agency theory), dan kos transaksi ekonomi (transaction cost economics). Paradigma public choice theory mengatakan bahwa sikap para karyawan suatu organisasi sebagai manusia cenderung terdorong oleh kepentingan mereka sendiri sehingga diperlukan suatu sistem akuntansi yang lebih informatif untuk mengurangi kecenderungan tersebut. Agency theory menyatakan bahwa manusia cenderung memaksimalkan kepentingan mereka sendiri. Sementara itu, paradigma transaction cost economics berfokus pada pengoptimalan struktur tata kelola organisasi.

\section{Teori Implementasi}

Implementasi kebijakan pada prinsipnya adalah cara agar sebuah kebijakan dapat mencapai tujuannya (Madjid dan Ashari, 2013). Dalam mengkaji implementasi kebijakan, Edwards (1980) menjawab dua pertanyaan penting dalam implementasi yaitu prakondisi-prakondisi apa yang diperlukan sehingga suatu implementasi kebijak- 
an dapat berhasil dan hambatan apa yang mengakibatkan gagalnya suatu implementasi kebijakan. Terkait dengan hal itu, terdapat empat aspek yang menentukan keberhasilan implementasi kebijakan publik, yaitu komunikasi, sumber daya, disposisi atau komitmen, dan struktur birokrasi. Keempat aspek tersebut harus dilaksanakan secara simultan karena antara satu dengan yang lainnya memiliki hubungan yang erat.

Menurut Edwards (1980) dari aspek komunikasi, informasi mengenai kebijakan publik perlu disampaikan kepada pelaku kebijakan agar para pelaku kebijakan dapat menjalankan kebijakan tersebut. Dari aspek sumber daya, suatu kebijakan tidak dapat dilaksanakan apabila pelaksana kebijakan tidak memiliki sumber daya yang memadai. Dari aspek disposisi, suatu kebijakan tidak dapat dilaksanakan apabila pelaksana tidak memiliki komitmen untuk melaksanakan kebijakan tersebut. Sementara itu, implementasi masih akan gagal apabila struktur birokrasi yang ada menghalangi koordinasi yang diperlukan dalam melaksanakan kebijakan.

\section{Standar Akuntansi Pemerintahan}

Salah satu upaya konkrit untuk mewujudkan transparansi dan akuntabilitas pengelolaan keuangan negara adalah penyampaian laporan pertanggungjawaban keuangan pemerintah. Laporan tersebut harus memenuhi prinsip tepat waktu dan disusun dengan mengikuti standar akuntansi pemerintahan yang telah diterima secara umum (Nugraha, 2009).

Menurut Budiono (2016), Standar Akuntansi Pemerintahan (SAP) merupakan persyaratan yang mempunyai kekuatan hukum dalam upaya meningkatkan kualitas laporan keuangan pemerintah di Indonesia. Menurut Sinaga (2005) SAP merupakan pedoman untuk menyatukan persepsi antara penyusun, pengguna, dan auditor. Oleh karena itu, laporan keuangan pemerintah yang merupakan hasil dari proses akuntansi yang berpedoman pada SAP diharapkan dapat digunakan sebagai alat komunikasi antara pemerintah dengan stakeholders sehingga tercipta pengelolaan keuangan negara yang transparan dan akuntabel.

\section{Ruang Lingkup SAP}

PP 71 Tahun 2010 tentang Standar Akuntansi Pemerintahan menyatakan bahwa SAP dilengkapi dengan Kerangka Konseptual Akuntansi Pemerintahan. Kerangka Konseptual Akuntansi Pemerintahan memuat konsep-konsep yang mendasari penyusunan dan pengembangan Standar Akuntansi Pemerintahan yang selanjutnya di- nyatakan dalam bentuk Pernyataan Standar Akuntansi Pemerintahan (PSAP). PSAP kemudian menetapkan pedoman untuk memperlakukan suatu objek yang harus dilaporkan mulai dari pengakuan, pengukuran/penilaian, sampai dengan penyajian dan pelaporan objek tersebut.

\section{Kebijakan Akuntansi Pemerintah}

UU 17 Tahun 2003 menyatakan bahwa Menteri Keuangan sebagai pelaksana kekuasaan atas pengelolaan fiskal mempunyai tugas antara lain menyusun laporan keuangan yang merupakan pertanggungjawaban pelaksanaan APBN. Pertanggungjawaban APBN tersebut merupakan laporan keuangan konsolidasi/gabungan yang dihasilkan oleh setiap entitas pelaporan. Agar laporan keuangan tersebut seragam sehingga dapat dikonsolidasikan dan diperbandingkan sebagaimana karakteristik kualitatif, maka perlu disusun suatu kebijakan akuntansi.

Kebijakan Akuntansi Pemerintah Pusat yang ditetapkan dalam PMK Nomor 219 Tahun 2013 merupakan turunan dari SAP dan berfungsi sebagai pedoman bagi entitas akuntansi dan pelaporan pada pemerintah pusat dalam menyusun laporan keuangan. kebijakan akuntansi pemerintah pusat mengatur mulai dari pos aset, kewajiban, ekuitas, pendapatan, dan beban.

\section{METODE PENELITIAN}

Penelitian ini menggunakan pendekatan kualitatif. Penelitian ini mendasarkan pada kata-kata, tindakan, dan perilaku orang-orang yang menjadi fokus dalam penelitian. Dengan kata lain, pendekatan kualitatif digunakan karena penelitian ini didesain untuk mendapatkan pemahaman mendalam mengenai fenomena yang diteliti dari sudut pandang partisipan dan sumber data yang lain sebagaimana yang dinyatakan oleh Harun dan Eggleton (2012).

\section{Lokasi dan Waktu Pelaksanaan}

Sesuai dengan judul penelitian, penelitian ini dilakukan di Inspektorat Jenderal Kementerian Keuangan. Waktu pelaksanaan penelitian dimulai dari tanggal 31 Oktober sampai dengan 23 Desember 2016.

\section{Jenis dan Sumber Data}

Data yang digunakan dalam penelitian ini merupakan data kualitatif, sedangkan sumber data yang akan digunakan dalam penelitian ini berasal dari data primer dan sekunder. 


\section{Teknik Pengumpulan Data}

Teknik pengumpulan data yang dilakukan dalam penelitian ini adalah wawancara, pengamatan, dan telaah dokumen. Wawancara dilakukan kepada sepuluh orang informan yang terkait langsung dengan penerapan SAP Akrual. Pengamatan dilakukan dalam proses akuntansi dan pengelolaan keuangan. Sementara itu, telaah dokumen dilakukan untuk mendapatkan dokumen pendukung fakta di lapangan.

Adapun informan yang terlibat dalam penelitian ini ditunjukkan dalam Tabel 2.

Tabel 2. Informan Penelitian

\begin{tabular}{lc}
\hline \multicolumn{1}{c}{ Jabatan/Peran Informan } & Jumlah \\
\hline $\begin{array}{l}\text { Kepala Bagian Perencanaan dan Keuangan } \\
\text { Periode 2008 s.d. 2016 }\end{array}$ & 1 \\
$\begin{array}{l}\text { Kepala Subbagian Akuntansi dan } \\
\text { Perpajakan }\end{array}$ & 1 \\
$\begin{array}{l}\text { Pelaksana Subbagian Akuntansi dan } \\
\text { Perpajakan }\end{array}$ & 2 \\
Pelaksana Subbagian Akuntansi dan & 1 \\
$\begin{array}{l}\text { Perpajakan Per. 2014 s.d. 2016 } \\
\text { Pengelola BMN }\end{array}$ & 2 \\
$\begin{array}{l}\text { Staf Biro Perencanaan dan Keuangan } \\
\text { Pengawas Internal/PIC Implementasi SAP }\end{array}$ & 2 \\
Berbasis Akrual Itjen & 1 \\
\hline
\end{tabular}

\section{Teknik Analisis Data}

Metode analisis data yang digunakan dalam penelitian ini merujuk pada enam langkah yang biasa digunakan dalam menganalisis data kualitatif sebagaimana yang direkomendasikan oleh Creswell (2012). Keenam langkah tersebut adalah pengorganisasian data, pengkodean data, pengembangan tema, penyajian dan pelaporan, interpretasi temuan, dan validasi temuan yang disajikan.

\section{HASIL PENELITIAN}

\section{Kesiapan Penerapan SAP Akrual}

Secara umum, persiapan yang dilakukan Itjen Kemenkeu dalam menghadapi dan menerapkan akuntansi berbasis akrual sudah baik. Aspekaspek kesiapan yang diteliti merujuk pada teori implementasi (Edwards, 1980), yaitu aspek komunikasi, aspek sumber daya, aspek komitmen organisasi, dan aspek struktur birokrasi, sebagaimana ditunjukkan dalam Tabel 3.

Tabel 3 dapat diketahui bagaimana kesiapan pernerapan SAP berbasis akrual. Terlihat bahwa aspek komunikasi sudah baik, aspek sumber daya manusia, sarana dan prasarana memadai, meskipun teknologi informasi dan keuangan kurang memadai, aspek komitmen organisasi sudah mendukung, dan aspek struktur birokrasi sudah mendukung.
Tabel 3. Kesiapan Penerapan SAP Berbasis Akrual

\begin{tabular}{cc}
\hline Aspek & \multicolumn{1}{c}{ Keterangan } \\
\hline Komunikasi & $\begin{array}{l}\text { Kebijakan Akuntansi Berbasis Akrual } \\
\text { telah dikomunikasikan baik secara lang- } \\
\text { sung melalui sosialisasi, forum konsolida- } \\
\text { si, rapat, dan media elektronik, maupun } \\
\text { secara tidak langsung melalui surat. }\end{array}$ \\
\hline Sumber Daya & - Seluruh pelaksana kebijakan berlatar \\
& belakang pendidikan tinggi di bidang \\
& ekonomi dan bisnis, dan dianggap \\
& kompeten karena telah melaksanakan \\
& tugasnya dengan baik. \\
& - Teknologi informasi yang digunakan \\
& belum memadai. \\
& Sumber daya keuangan tidak meng- \\
& alami peningkatan signifikan. \\
& Sarana dan prasarana telah memadai \\
& dan mendukung penerapan kebijakan \\
\hline Komitmen & $\begin{array}{l}\text { Seluruh pihak yang terlibat mulai dari } \\
\text { penyusun kebijakan sampai dengan pe- } \\
\text { Organisasi } \\
\text { laksana kebijakan berkomitmen untuk } \\
\text { menerapkan SAP berbasis akrual. }\end{array}$ \\
\hline Struktur & $\begin{array}{l}\text { Koordinasi antara penyusun laporan, } \\
\text { pengelola keuangan, dan pengelola BMN } \\
\text { berjalan dengan baik dan tidak meng- } \\
\text { halangi satu sama lain. }\end{array}$ \\
\hline &
\end{tabular}

\section{Aspek Komunikasi}

Dalam menerapkan akuntansi berbasis akrual, Inspektorat Jenderal (Itjen) berpedoman pada SAP berbasis akrual yang ditetapkan dalam bentuk peraturan pemerintah. Peraturan pemerintah tersebut kemudian diperinci lagi menjadi peraturan menteri dan peraturan direktur jenderal.

Agar peraturan tersebut dapat diketahui dan dilaksanakan, maka dilakukan sosialisasi kepada seluruh penyusun laporan keuangan. Seluruh informan dan dokumentasi dari situs resmi Direktorat Jenderal Perbendaharaan (DJPB) mengakui bahwa sosialisasi SAP berbasis akrual telah dilakukan. Sosialisasi tersebut dilakukan baik secara langsung maupun tidak langsung.

Informan 1 dan Informan 8 menyatakan bahwa sosialisasi secara langsung dilakukan pada level pimpinan dalam skala nasional. Sementara itu, pada tataran teknis di tingkat pelaksana, sosialisasi dilakukan secara tidak langsung. Menurut para pelaksana yang menjadi informan dalam penelitian ini, sosialisasi tidak langsung dilakukan melalui surat. Namun untuk mempercepat proses sosialisasi, surat tersebut di-scan dan dikirim via email kepada masing-masing satuan kerja.

Sejauh ini, seluruh peraturan dan pedoman yang telah diterbitkan dalam rangka penerapan akuntansi berbasis akrual sudah dianggap memadai oleh sebagian besar informan. Mereka menilai peraturan dan pedoman tersebut mudah 
untuk dipahami dan dilaksanakan. Peraturan dan pedoman tersebut biasanya dilampirkan dengan petunjuk teknis yang sangat rinci sehingga para pelaksana tinggal mengikuti langkah-langkahnya saja. Peraturan dan pedoman yang dilengkapi dengan petunjuk teknis yang sangat rinci tersebut dapat menghemat waktu dan dana para penyusun kebijakan sehingga tidak perlu dilakukan sosialisasi khusus untuk setiap pedoman dan peraturan yang diterbitkan. Bahkan Informan 2 mengatakan bahwa untuk peraturan yang pelaksanaannya menggunakan aplikasi atau sistem informasi, pelaksanaan aturan tersebut biasanya sudah dimasukkan ke dalam sistem sehingga para pelaksana hanya diminta untuk update aplikasinya.

Namun, salah satu kekurangan sosialisasi tidak langsung adalah komunikasi yang dilakukan satu arah. Untuk mengatasi hal itu, apabila ada pertanyaan atau ketidakpahaman mengenai peraturan dan pedoman yang disosialisasikan, maka pelaksana kebijakan dapat berkomunikasi langsung dengan Biro Perencanaan dan Keuangan (Rocankeu) sebagai pembina dan DJPB sebagai penyusun kebijakan melalui media elektronik sebagaimana disampaikan oleh Informan 3, Informan 5, Informan 6, dan Informan 8.

Di luar aturan main dan pedoman teknis untuk menerapkan SAP Akrual, hampir seluruh informan sepakat bahwa kebijakan akuntansi berbasis akrual yang diterapkan saat ini belum mencerminkan praktik akuntansi berbasis akrual. Mereka mengatakan bahwa pengakuan dan pencatatan atas Pendapatan Laporan Operasional (LO), Beban, dan Aset dilakukan pada saat terjadi penerimaan dan pengeluaran ke dan dari kas negara. Pelaksanaan akrual hanya dilakukan pada saat pelaporan dengan melakukan jurnal penyesuaian pada akhir periode akuntansi.

Pelaksanaan akuntansi berbasis akrual yang dianggap belum akrual tersebut ternyata menjadi temuan oleh Badan Pemeriksa Keuangan dalam Laporan Hasil Pemeriksaan (LHP). Menurut Badan Pemeriksa Keuangan (BPK), praktik tersebut dapat menimbulkan risiko tidak tercatatnya seluruh hak dan kewajiban Pemerintah yang layak diakui sebagai aset, pendapatan, dan beban dalam satu periode akuntansi.

\section{Aspek Sumber Daya}

Penelitian ini mengacu pada penelitian yang dilakukan oleh Rosada (2016). Oleh karena itu, sumber daya yang didalami dalam penelitian ini meliputi sumber daya manusia, sumber daya keuangan, sarana dan prasarana, serta teknologi informasi.
Unit yang terkait dalam penerapan SAP berbasis akrual adalah Subbagian Akuntansi dan Perpajakan dan Subbagian Perlengkapan dan Pengadaan Barang Milik Negara (P2BMN). Subbagian Akuntansi dan Perpajakan terdiri dari tiga orang pelaksana. Dari tiga orang pelaksana tersebut, dua diantaranya memiliki latar belakang pendidikan tinggi di bidang ekonomi dan bisnis. Sedangkan satu orang lainnya berpendidikan SLTA, namun tidak diberikan tanggung jawab sebagai penyusun laporan keuangan. Sementara itu, Subbagian P2BMN terdiri atas delapan orang pelaksana. Dari delapan orang pelaksana tersebut, dua orang diantaranya diberikan tanggung jawab untuk menyusun laporan BMN yang dilampirkan dalam laporan keuangan. Dua orang tersebut memiliki latar belakang pendidikan tinggi di bidang ekonomi dan bisnis. Oleh karena itu, secara kompetensi, seluruh pelaksana kebijakan memiliki latar belakang pendidikan tinggi di bidang ekonomi dan bisnis.

Berdasarkan database kepegawai-an, seluruh pelaksana kebijakan SAP berbasis akrual belum pernah mengikuti diklat terkait pengelolaan keuangan dan penyusunan laporan keuangan. Namun, Informan 3 yang merupakan salah satu pelaksana kebijakan mengaku pernah mengikuti workshop yang diadakan oleh Pusat Pendidikan dan Pelatihan Anggaran dan Perbendaharaan. Sementara itu, pelaksana lainnya yang belum pernah mengikuti diklat mengaku dapat melaksanakan tugas dan tanggung jawabnya karena diajarkan oleh pelaksana sebelumnya.

Walaupun belum pernah mengikuti diklat khusus SAP berbasis akrual, Kepala Bagian Perencanaan dan Keuangan, Kepala Subbagian Akuntansi dan Perpajakan, dan Staf di Biro Perencanaan dan Keuangan menganggap para pelaksana telah kompeten dan dapat melaksanakan tugasnya dengan baik. Hal ini dikarenakan mereka sebelumnya sudah pernah mengikuti diklat tentang pengelolaan keuangan dan penyusunan laporan keuangan.

Dalam menerapkan SAP Berbasis Akrual, Itjen telah menggunakan teknologi informasi sebagaimana dikatakan oleh seluruh informan. Sebagian besar teknologi informasi dikembangkan dan didistribusikan oleh DJPB sebagai penyusun kebijakan. Aplikasi tersebut terdiri dari aplikasi Sistem Akuntansi Basis Akrual (SAIBA), Sistem Aplikasi Satker (SAS), Sistem Informasi Manajemen dan Akuntansi (SIMAK BMN), Persediaan, e-Rekon, dan Online Monitoring Sistem Perbendaharaan dan Anggaran Negara (OM SPAN). Selain itu, Itjen juga menggunakan aplikasi yang dikembangkan sendiri, bernama Sistem Informasi Keuangan (SISKA). 
Dari ketujuh aplikasi tersebut, tiga diantaranya merupakan aplikasi yang baru digunakan pada tahun 2015, yaitu SAIBA, e-Rekon, dan OM SPAN. Sementara, aplikasi lainnya telah digunakan sebelum diterapkannya SAP Akrual. Walaupun telah digunakan lebih dari satu tahun, namun hampir seluruh informan menganggap bahwa aplikasi-aplikasi tersebut masih memiliki beberapa kendala. Kendala tersebut diantaranya adalah ketidakakuratan nilai BMN yang disajikan dalam SIMAK BMN dan kelemahan pengendalian dalam aplikasi Persediaan.

Banyaknya aplikasi yang digunakan untuk mendukung penyusunan laporan keuangan menyebabkan proses implementasi akuntansi berbasis akrual menjadi tidak efisien. Selain itu juga dapat meningkatkan risiko salah saji. Oleh karena itu perlu dikembangkan suatu aplikasi penyusun laporan keuangan yang terintegrasi. Baik terintegrasi secara internal, maupun secara eksternal dengan Bendahara Umum Negara.

Informan 3 dan Informan 4 percaya bahwa permasalahan terkait aplikasi yang digunakan saat ini dapat diselesaikan dengan aplikasi terintegrasi. Sampai saat ini, aplikasi terintegrasi yang dinamakan SAKTI sudah dalam tahap piloting, dan dapat digunakan setelah tahapan piloting berhasil dilaksanakan.

Terkait dengan sumber daya keuangan, penerapan SAP berbasis akrual tidak memberikan dampak yang signifikan dalam anggaran Itjen. Menurut Informan 1, hal itu disebabkan oleh transaksi yang tidak terlalu rumit dan kompetensi SDM yang memadai. Kenaikan biaya dalam rangka penerapan akuntansi berbasis akrual hanya disebabkan oleh penambahan jadwal konsolidasi yang semula hanya dilakukan semesteran, pada tahun 2015 dilakukan triwulanan dan ditambah dengan adanya kebijakan penyusunan pseudo laporan keuangan mulai bulan Oktober sampai dengan akhir periode pelaporan.

Dalam rangka mendukung penerapan SAP berbasis akrual, para informan mengatakan bahwa sarana dan prasarana yang disediakan sudah cukup. Berdasarkan hasil observasi, sarana dan prasarana yang disediakan antara lain 1 buah meja, kursi dan perangkat komputer yang memadai untuk setiap staf, 1 buah laptop, 1 buah alat scanner, dan satu buah printer.

\section{Aspek Komitmen Organisasi}

Keberhasilan implementasi SAP berbasis akrual sangat ditentukan oleh besarnya dukungan dan komitmen dari seluruh pihak, mulai dari penyusun sampai dengan pelaksana kebijakan. Berdasarkan Majalah Treasury Indonesia (2014),
DJPB sebagai penyusun dan penanggung jawab kebijakan telah melakukan penguatan komitmen dengan para pengambil keputusan tertinggi pada masing-masing instansi kementerian negara/ lembaga dan pemerintah daerah, serta stakeholder kunci lainnya. Rangkaian kegiatan yang telah dilakukan dalam rangka penguatan komitmen ini adalah high level stakeholder meeting, deklarasi implementasi akuntansi berbasis akrual, dan sosialisasi kebijakan.

Penguatan komitmen tersebut berjalan dengan efektif di Kementerian Keuangan. Rocankeu sebagai pembina dan pengambil keputusan tertinggi terkait dengan akuntansi dan pelaporan di Kementerian Keuangan telah menunjukkan langkah konkret dalam mendukung penerapan SAP berbasis akrual. Langkah dukungan yang telah dilakukan adalah penerbitan buku-buku dan surat edaran sebagai pedoman dan petunjuk penerapan, dan helpdesk perencanaan dan keuangan untuk meningkatkan komunikasi dan koordinasi dengan pelaksana kebijakan.

Sementara itu, Itjen sebagai pelaksana kebijakan telah menyatakan dukungannya sebagaimana dikatakan oleh hampir seluruh informan. Sebagian dari mereka menganggap bahwa basis akrual merupakan basis akuntansi yang lebih baik dari basis akuntansi kas yang digunakan selama ini, sedangkan sebagian yang lain menganggap hal itu merupakan salah satu upaya dalam mewujudkan kepatuhan terhadap peraturan yang ada.

\section{Aspek Struktur Birokrasi}

Salah satu aspek struktural yang paling dasar dari suatu organisasi adalah prosedur kerja standar (SOP). Itjen Kemenkeu telah memutakhirkan SOP dalam rangka penerapan SAP berbasis akrual sebagaimana yang disampaikan oleh Informan 1, Informan 4, dan Informan 5. Namun menurut Informan 2 dan Informan 3, SOP yang dimiliki oleh Subbagian Akuntansi dan Perpajakan masih belum dimutakhirkan.

Penuturan dari Informan 2 dan Informan 3 didukung oleh bukti dokumen. Dokumen berupa SOP yang didapatkan dari Bagian Organisasi dan Analisis Hasil Pemeriksaan (BOAHP) yang berwenang menerbitkan SOP masih tertanggal 27 Desember 2013 dan masih menggunakan basis cash toward accrual. Walaupun begitu, SOP tersebut tidak menjadi penghambat dalam implementasi SAP berbasis akrual.

Sifat kedua dari struktur birokrasi yang berpengaruh dalam pelaksanaan kebijakan adalah fragmentasi organisasi. Tanggung jawab atas suatu kebijakan sering kali dipisah dan tersebar diantara beberapa unit dalam organisasi. Pemi- 
sahan fungsi dan wewenang juga merupakan prosedur yang direkomendasikan oleh pengendalian internal.

Dalam menyusun laporan keuangan berdasarkan SAP berbasis akrual, Subbagian Akuntansi dan Perpajakan berkoordinasi dengan subbagian Perbendaharaan dan subbagian P2BMN. Menurut Informan 2, Informan 3, dan Informan 4 yang masih aktif di Subbagian Akuntansi dan Perpajakan, koordinasi dengan subbagian Perbendaharaan dapat dikatakan baik, namun dengan subbagian P2BMN tidak dapat dikatakan lancar. Menurut Informan 2 hal itu disebabkan oleh kurangnya SDM. Namun menurut Informan 1 hal itu membuat hubungan semakin baik dan saling bahu-membahu antar bagian.

\section{Implementasi SAP Berbasis Akrual}

Implementasi SAP berbasis akrual dinilai dengan membandingkan antara kebijakan akuntansi yang tertuang dalam PMK 219 Tahun 2013 dan penerapannya. Tabel 4 di bawah ini menunjukkan nilai implementasi SAP Berbasis Akrual.

Dari Tabel 4, diketahui bahwa Itjen mendapatkan nilai hasil akhir implementasi sebesar $93,40 \%$. Berdasarkan pedoman umum evaluasi yang diatur dalam Permenpan-RB Nomor 12 Tahun 2015, nilai implementasi sebesar 93,40\% masuk dalam kategori AA dengan interpretasi Sangat Memuaskan.

Di satu sisi, nilai sebesar 93,40\% menunjukkan penerapan yang sangat baik, namun di sisi lain nilai tersebut menunjukkan bahwa masih terdapat kekurangan. Dari Tabel 4, diketahui bahwa akun yang masih belum sesuai dengan PMK 219 Tahun 2013 adalah akun Persediaan, Aset Tetap, Aset Tak Berwujud, Utang Kepada Pihak Ketiga, dan hampir seluruh akun beban operasional.

\section{Persediaan}

Berdasarkan hasil observasi, ketidaksesuaian antara praktik dengan PMK 219 Tahun 2013 pada akun Persediaan terjadi dalam proses pengakuan. Dalam praktiknya, Itjen baru mengakui dan mencatat Persediaan setelah terjadi pengeluaran kas dengan SP2D sebagai dokumen sumber. Selain itu, Itjen juga melakukan pencatatan persediaan secara periodik setiap akhir bulan.

Berdasarkan PMK 219 Tahun 2013, Persediaan seharusnya dicatat pada saat potensi manfaat ekonomi masa depan diperoleh dan mempunyai nilai atau biaya yang dapat diukur dengan andal yang didukung oleh bukti/dokumen yang dapat diverifikasi dan di dalamnya terdapat elemen harga barang persediaan sehingga biaya tersebut dapat diukur secara andal, jujur, dapat diverifikasi, dan bersifat netral, atau pada saat diterima atau hak kepemilikannya dan/atau kepenguasaannya berpindah dengan dokumen sumber yang digunakan sebagai pengakuan perolehan persediaan adalah faktur, kuitansi, atau Berita Acara Serah Terima (BAST).

Tabel 4. Nilai Implementasi SAP Berbasis Akrual

\begin{tabular}{lr}
\hline \multicolumn{1}{c}{ AKUN } & SKOR \\
\hline Kas di Bendahara Pengeluaran & $100.00 \%$ \\
Kas Lainnya dan Setara Kas & $100.00 \%$ \\
Beban Dibayar di Muka & $100.00 \%$ \\
Bagian Lancar Tagihan Tuntutan & $100.00 \%$ \\
Perbendaharaan/Tuntutan Ganti Rugi & $87.50 \%$ \\
Persediaan & $89.58 \%$ \\
Aset Tetap & $66.67 \%$ \\
Aset Tidak Berwujud & $100.00 \%$ \\
Aset Lain-lain & $83.33 \%$ \\
Utang Kepada Pihak Ketiga & $100.00 \%$ \\
Uang Muka dari KPPN & $100.00 \%$ \\
Utang Jangka Pendek Lainnya & $100.00 \%$ \\
Ekuitas & $100.00 \%$ \\
Pendapatan Bukan Pajak-LO & $100.00 \%$ \\
Beban Pegawai & $91.67 \%$ \\
Beban Persediaan & $87.50 \%$ \\
Beban Barang dan Jasa & $87.50 \%$ \\
Beban Pemeliharaan & $93.40 \%$ \\
Nilai Implementasi Akuntansi Berbasis & \\
Akrual & \\
\hline
\end{tabular}

Menurut Informan 1, Informan 4, Informan 6 , dan Informan 8, ketidaktepatan waktu pengakuan Persediaan terjadi karena tidak terintegerasinya aplikasi yang digunakan. Di satu sisi, aplikasi SAIBA yang digunakan dalam penyusunan laporan keuangan mengakui Persediaan setelah terjadi pengeluaran kas dengan dokumen sumber berupa SP2D. Di sisi lain, aplikasi Persediaan yang digunakan dalam pengelolaan persediaan seharusnya sudah dapat melakukan pencatatan pada saat persediaan tersebut diterima. Tidak terintegrasinya kedua aplikasi tersebut menurut Informan 2 disebabkan karena kedua aplikasi tersebut dikembangkan oleh pengembang yang berbeda.

Keterlambatan pengakuan tersebut akan menimbulkan risiko tidak tercatatnya sebagian aset pemerintah. Apalagi apabila pembelian barang persediaan tersebut dilakukan dengan mekanisme uang persediaan (UP) dimana belanja atas barang persediaan baru diakui setelah Bendahara Pengeluaran melakukan pertanggungja-waban UP. Hal tersebut diperparah dengan pengakuan operator sekaligus pengelola persediaan yang mengatakan bahwa SP2D atas pembelian barang dengan mekanisme UP sering tidak disampaikan (ke operator aplikasi Persediaan) sehingga pengakuan 
dan perekaman Persediaan tidak dilakukan dengan tepat waktu. Praktik tersebut akan mengakibatkan data pada aplikasi Persediaan menjadi tidak akurat.

Selain itu, PMK 219 Tahun 2013 juga mengatur bahwa Persediaan dicatat menggunakan metode perpetual, setiap terjadi transaksi masuk maupun keluar. Praktik tersebut dapat meningkatkan risiko terlambatnya pemesanan kembali barang persediaan yang akan habis sehingga dapat menghambat kegiatan operasional Itjen.

Menurut Informan 7, ketidaktaatan tersebut terjadi karena kurangnya SDM untuk mencatat setiap kali terjadi transaksi. Satu orang pengelola persediaan harus melaksanakan seluruh fungsi pengelolaan mulai dari pengadaan, penyimpanan, penatausahaan, sampai dengan pencatatan dan pelaporan. Ditambah lagi, pada akhir periode pelaporan, PMK 219 Tahun 2013 mensyaratkan dilakukannya inventarisasi fisik dalam rangka penyajian Beban Persediaan.

\section{Aset Tetap}

Permasalahan pada akun Aset Tetap terjadi pada tahap pengakuan. Sebagaimana akun Persediaan, ketidaksesuaian proses pengakuan pada akun Aset Tetap terjadi karena pencatatan baru dilakukan setelah diterbitkannya SP2D. Selain itu, terdapat hal-hal yang belum diungkapkan dalam CaLK.

Sebagaimana yang terjadi pada akun Persediaan, keterlambatan pengakuan disebabkan oleh tidak terintegrasinya aplikasi SIMAK BMN dengan aplikasi SAIBA. Keterlambatan pengakuan tersebut juga akan membuat informasi Aset Tetap yang disajikan tidak akurat.

Sementara itu, dalam proses penyajian dan pengungkapan pada akun Aset Tetap, PMK 219 Tahun 2013 mensyaratkan adanya hal lain yang perlu diungkapkan. Hal lain yang perlu diungkapkan tersebut adalah eksistensi dan batasan hak milik Aset Tetap dan jumlah komitmen untuk akuisisi Aset Tetap. Dalam laporan keuangannya, Itjen tidak mengungkapkan hal tersebut.

Tidak diungkapkannya suatu hal yang perlu diungkapkan dapat terjadi karena komunikasi yang kurang efektif. Seharusnya terdapat peraturan atau pedoman yang mengatur lebih rinci mengenai hal lain yang perlu diungkapkan dalam CaLK.

\section{Aset Tak Berwujud}

Permasalahan pada akun Aset Tak Berwujud juga terjadi pada tahap pengakuan. Sebagaimana yang terjadi pada akun Aset Tetap, keterlambatan pengakuan disebabkan oleh tidak terintegrasinya aplikasi SIMAK BMN dengan aplikasi SAIBA. Keterlambatan pengakuan tersebut juga akan membuat informasi Aset Tak Berwujud yang disajikan tidak akurat.

Sementara itu, dalam proses penyajian dan pengungkapan pada akun Aset Tak Berwujud, PMK 219 Tahun 2013 mensyaratkan diungkapkannya masa manfaat tiap aset tak berwujud beserta metode amortisasi yang digunakan, nilai tercatat bruto, jumlah amortisasai yang telah dilakukan dan nilai buku aset tak berwujud, serta pengungkapan mengenai penambahan maupun penurunan nilai pada awal dan akhir periode, termasuk penghentian dan pelepasan aset tak berwujud.

Namun, peraturan tersebut tidak mengatur lebih jelas mengenai metode amortisasi dan cara perhitungannya sebagaimana pada bagian Aset Tetap. Akibatnya, terdapat hal yang tidak diungkapkan dan tidak menggambarkan nilai Aset Tak Berwujud yang sebenarnya.

\section{Utang Kepada Pihak Ketiga}

Menurut PMK 219 Tahun 2013, Utang Kepada Pihak Ketiga diakui pada saat Pemerintah telah menerima hak atas barang/jasa, termasuk barang dalam perjalanan yang telah menjadi haknya. Namun dalam praktiknya hal itu tidak dapat di lakukan. Utang Kepada Pihak Ketiga baru dicatat pada akhir periode pelaporan dengan menyusun jurnal penyesuaian akrual untuk mengakui adanya kewajiban dan beban.

Dalam rangka menyusun jurnal penyesuaian, penyusun laporan keuangan harus mengidentifikasi dan menginventari-sir barang/jasa yang belum dibayarkan sampai dengan akhir periode pelaporan. Menurut Badan Pemeriksa Keuangan (BPK) menyatakan dalam Laporan Hasil Pemeriksaan (LHP) Kinerja Atas Pengendalian Internal Terhadap Pelaporan Keuangan Pemerintah Pusat Berbasis Akrual, hal itu dapat meningkatkan risiko tidak tercatatnya seluruh hak dan kewajiban pemerintah yang layak diakui sebagai beban/ pendapatan dalam satu periode pelaporan.

Praktik tersebut diakibatkan oleh aplikasi SAIBA yang belum memadai dan tidak dapat mengakomodir pencatatan transaksi pada saat diterimanya hak atau timbulnya kewajiban. Selain itu, BPK juga menyatakan bahwa Menteri Keuangan belum membuat aturan yang jelas mengenai dokumen sumber pendukung sebagai dasar pencatatan jurnal penyesuaian. PMK 219 Tahun 2013 tidak mengatur secara rinci dokumen sumber yang digunakan. 


\section{Beban Operasional}

Sebagaimana permasalahan pada akun-akun sebelumnya, permasalahan dalam tahap pengakuan pada sebagian besar akun beban operasional terjadi karena aplikasi SAIBA yang belum memadai dan tidak dapat mengakomodir pencatatan transaksi pada saat diterimanya hak atau timbulnya kewajiban. Keterlambatan tersebut dapat meningkatkan risiko tidak tercatatnya kewajiban pemerintah.

Sementara itu, untuk akun Beban Persediaan, ketidaksesuaian proses pengakuan terjadi karena kurangnya SDM. Menurut PMK 219 Tahun 2013, beban diakui saat terjadinya konsumsi aset non kas dalam kegiatan operasional pemerintah. Artinya, Beban Persediaan seharusnya dicatat pada saat terjadi mutasi keluar, atau penggunaan barang persediaan berdasarkan Surat Perintah Mengeluarkan Barang (SPMB).

\section{KESIMPULAN}

Berdasarkan hasil penelitian, dapat ditarik kesimpulan sebagai berikut: pertama, Secara umum, kesiapan Itjen Kemenkeu dalam menerapkan sistem akuntansi akrual sudah baik karena adanya dukungan dari aspek komunikasi, sumber daya, teknologi informasi, komitmen organisasi, dan struktur organisasi; dan kedua, Penerapan sistem akuntansi akrual di Itjen Kemenkeu sudah dilakukan dengan sangat memuaskan dan mendapatkan nilai sebesar $93,40 \%$.

\section{IMPLIKASI DAN KETERBATASAN}

Berdasarkan hasil penelitian, terdapat beberapa implikasi sebagai berikut: pertama, Itjen perlu membuat policy recommendation kepada DJPB agar PMK 219 Tahun 2013 dilengkapi dengan ketentuan yang jelas mengenai dokumen sumber pendukung sebagai dasar pencatatan jurnal penyesuaian; kedua, Itjen perlu memberikan masukan kepada DJPB untuk melakukan penyempurnaan aplikasi yang digunakan agar dapat mengakomodir pencatatan transaksi pada saat diterimanya hak atau timbulnya kewajiban, dan mengimplemen-tasikan amortisasi Aset Tak Berwujud; ketiga, Itjen perlu mengevaluasi kebijakan SDM-nya, dan mengembangkan knowledge management untuk mengurangi risiko terhambatnya pekerjaan apabila ada pegawai yang berhalangan; dan keempat, dengan nilai implementasi sebesar 93,40\%, Itjen dapat dijadikan benchmark penerapan akuntansi berbasis akrual bagi instansi lain.
Penelitian ini memiliki beberapa keterbatasan yang perlu diperbaiki pada penelitian-penelitian selanjutnya, yaitu sebagai berikut: pertama, Penelitian hanya dilakukan pada salah satu instansi sehingga memiliki keterbatasan generalisasi. Oleh karena itu, penelitian terkait akuntansi sektor publik selanjutnya disarankan dilakukan pada instansi lainnya; kedua, Informan dalam penelitian ini rata-rata memiliki masa jabatan dan pengalaman penyusunan laporan keuangan hanya sekitar dua sampai dengan tiga tahun sehingga sulit memberikan perbandingan antara akuntansi berbasis CTA dengan akuntansi berbasis akrual. Oleh karena itu bagi penelitian selanjutnya dapat mempertim-bangkan masa kerja pegawai; dan ketiga, Subjek penelitian ini adalah Itjen yang merupakan suatu unit cost center (pusat biaya) yang tidak memiliki kewenangan untuk mencari keuntungan dan melakukan investasi sehingga manfaat penerapan akuntansi berbasis akrual tidak dapat terlihat jelas. Penelitian selanjutnya disarankan untuk menggunakan subjek lain yang memiliki fungsi sebagai responsibility center agar mendapat gambaran penerapan akuntansi berbasis akrual yang lebih komprehensif.

\section{DAFTAR PUSTAKA}

Broadbent, J and Guthrie J (2008), "Public Sector to Public Services: 20 years of 'Contextual' Accounting Research", Accounting Auditing \& Accountability Journal, 21(2), 129-169.

Budiono, A (2016), Penerapan Standar Akuntansi Persediaan Berbasis Akrual Pada Pemerintah Kota Tangerang Tahun 2015, Tesis, Jakarta, STIA LAN.

Creswell, J. W (2012), Educational Research: Planning, Conducting, and Evaluating Quantitative and Qualitative Research, $4^{\text {th }}$ edition, Pearson Education, Boston.

Dambrin, C, Lambert, C, and Sponem, S (2007), "Control and change-analysis of the process and institutionalization", Management Accounting Research, 18(2), 172-208.

Edwards, George C (1980), Implementing Public Policy, Congressional Quarterly Press.

El-Batanoni, K. dan Jones, R. H (1996), "Governmental accounting in Sudan", Governmental and Nonprofit Accounting, 209-217.

Harun, H (2012), Public Sector Accounting Reforms in the Indonesian Post-Suharto Era, Thesis, The University of Waikato.

Harun, H., and Eggleton, I.R.C (2012), "Institutionalization of Accrual Accounting in the Indonesian Public Sector", Journal of Accounting \& Organizational Change, 8(3), 257-285.

Harun, H., and Kamase, H.P (2012), "Accounting Change and Institutional Capacity: The Case 
of a Provincial Government in Indonesia", Australasian Accounting Business and Finance Journal, 6(2), 35-50.

Kementerian Keuangan (2015), Kementerian Keuangan Menyelenggarakan Kick Off Implementasi Akuntansi Pemerintahan Berbasis Akrual Tahun 2015, Keterangan Pers.

Kusmanadji (2014), "Penerapan Basis Akrual untuk Pelaporan Keuangan Pemerintah: Perkembangan Global dan Perjalanan Indonesia Menuju Penerapan Basis Akrual Penuh pada 2015”, Jurnal Informasi Keuangan dan Akuntansi Infoartha, 3 (12), 1-12.

Lapsley, I., Pallot, J (2000), "Accounting, management and organizational change: a comparative study of local government", Management Accounting Research, 11(2), 213-222.

Lye, J., Perera, H., and Rahman, A (2005), "The evolution of accruals-based Crown (government) financial statement in New Zealand", Accounting, Auditing, and Accountability, 18(6), 784-915.

Madjid, N.C. dan Ashari, H (2013), Analisis Implementasi Anggaran Berbasis Kinerja (Studi Kasus pada Badan Pendidikan dan Pelatihan Keuangan), Kajian Akademis BPPK Tahun Anggaran 2013.

Nugraha, W (2009), Pengaruh Pemahaman atas Standar Akuntansi Pemerintahan terhadap Kualitas Laporan Keuangan melalui Keefektifan Pelaksanaan Sistem Akuntansi Instansi sebagai Variabel Mediasi, Skripsi, Bandung, Unversitas Padjajaran.

Rahaman, A. S (2009), "Independent financial auditing and the crusade against government sector financial mismanagement in Ghana", Qualitative Research in Accounting \& Management, 6(4), 224-246.
Republik Indonesia (2003), Undang-Undang Nomor 17 Tahun 2003 tentang Keuangan Negara. Tambahan Lembaran Negara RI Tahun 2003 Nomor 4286, Sekretariat Negara, Jakarta.

(2005), Peraturan Pemerintah Nomor 24 Tahun 2005 tentang Standar Akuntansi Pemerintahan, Tambahan Lembaran Negara RI Tahun 2005 Nomor 4503, Sekretariat Negara, Jakarta.

(2010), Peraturan Pemerintah Nomor 71 Tahun 2010 tentang Standar Akuntansi Pemerintahan, Tambahan Lembaran Negara RI Tahun 2010 Nomor 5165, Sekretariat Negara, Jakarta.

(2013), Peraturan Menteri Keuangan RI Nomor 219/PMK.05/2013 tanggal 31 Desember 2013 tentang Kebijakan Akuntansi Pemerintah Pusat.

(2015), Peraturan Menteri Pemberdayaan Aparatur Negara dan Reformasi Birokrasi RI Nomor 12 Tahun 2005 tanggal 2 Juli 2015 tentang Pedoman Evaluasi atas Implementasi Sistem Akuntabilitas Kinerja Instansi Pemerintah, Berita Negara RI Tahun 2015 Nomor 986. Jakarta.

Ryan, C (1998), "The introduction of accrual reporting policy in the Australian public sector: an agenda setting explanation", Accounting, Auditing and Accountability Journal, 11(5), 618-539.

Sinaga, Jamason (2005), "Selamat Datang Standar Akuntansi Pemerintahan", www.ksap. org/Riset\&Artikel/Art8.pdf

Sharma, U., Lawrence, S (2005), "Public sector reform, global trends vs. local needs: the case of a state rental organization in Fiji”, Journal of Accounting and Organizational Change, 1(2) $141-164$

Widodo, J (2010), Analisis Kebijakan Publik, Konsep dan Aplikasi Analisis Kebijakan Publik, Bayu Media, Malang. 